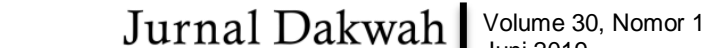 \\ Juni 2019 \\ P-ISSN: 1412-0348 \\ E-ISSN: 2654-3877
}

DOI: $10.24014 /$ jdr.v30i1.6999

\section{PENERAPAN KOMUNIKASI TERAPEUTIK PADA ANAK PENYANDANG DOWN SYNDROME MELALUI PELAYANAN TERAPI WICARA DI RSUD PROF. DR. MARGONO SOEKARJO PURWOKERTO}

\author{
Resya Nur Intan Putri ${ }^{1}$, S. Bekti Istiyanto ${ }^{2}$ \\ ${ }^{1,2}$ Jurusan Ilmu Komunikasi Universitas Jenderal Soedirman Purwokerto \\ Email: resyanurintanputri@gmail.com
}

\section{Kata kunci}

Komunikasi Terapetik, Terapi, Down

Syndrome

\begin{abstract}
Abstrak
Penelitian ini berbicara mengenai proses komunikasi terapeutik yang dilakukan tenaga medis yaitu terapis wicara dengan pasien anak berkebutuhan khusus yang dispesifikan pada penyandang down syndrome di RSUD Prof. Dr. Margono Soekarjo Purwokerto. Penelitian ini bertujuan untuk mengetahui proses ataupun cara dalam melakukan komunikasi terapeutik yang dilakukan oleh terapis wicara dengan pasien anak penyandang down syndrome di RSUD Prof. Dr. Margono Soekarjo Purwokerto. Metode yang digunakan dalam penelitian ini adalah metode kualitatif eksploratif. Hasil dari penelitian ini menunjukan bahwa untuk melakukan sebuah komunikasi terapeutik dengan pasien anak dapat dilakukan dengan menggunakan beberapa metode dalam terapi bahasa, misalnya metode modeling dan self talk-paralel talk. Selanjutnya, terdapat proses komunikasi terapeutik yang dilakukan oleh terapis yang terdiri dari tahap pra-interaksi, perkenalan, orientasi, kerja dan terminasi. Dalam komunikasi terapeutik yang terjalin, juga terjadi pertukaran pesan serta hambatan-hambatan yang dialami oleh terapis dalam melakukan proses tersebut.
\end{abstract}

\section{Keywords \\ Therapeutic \\ Communication, \\ Therapy, Down \\ Syndrome.}

\begin{abstract}
This study talks about the therapeutic communication process carried out by medical personnel (speech therapists) with patients with special needs who are specified in persons with Down syndrome at Prof. RSUD. Dr. Margono Soekarjo Purwokerto. This study aims to determine the process or method of conducting therapeutic communication by speech therapists with pediatric patients with Down syndrome in Prof. RSUD. Dr. Margono Soekarjo Purwokerto. The method used in this study is an explorative qualitative method. The results of this study indicate that to conduct a therapeutic communication with pediatric patients can be done using several methods in language therapy, for example such as modeling and self talk-parallel talk methods. Furthermore, there is a therapeutic communication process carried out by a therapist consisting of the stages of pre-interaction, introduction, orientation, work, and termination. In therapeutic communication that is interwoven there is also the exchange of messages and obstacles experienced by therapists in carrying out the process.
\end{abstract}

\section{Pendahuluan}

Masa anak-anak merupakan salah satu fase perkembangan dalam kehidupan manusia. Pada fase ini manusia akan mengalami tumbuh kembang dalam berbagai hal dengan lebih cepat dibandingkan fase lain seperti fase remaja ataupun dewasa. Pada fase anak-anak, 
manusia akan mengalami tahap awal pekembangan secara fisik dan emosional yang sangat dipengaruhi oleh faktor lingkungan. Seperti yang diungkapkan oleh Hidayat (2005:15) bahwa faktor lingkungan sesungguhnya memegang peranan esensial dalam menentukan tercapai atau tidaknya potensi yang telah dimiliki. Maka dari itu, tumbuh kembang anak menjadi sebuah hal yang patut diperhatikan orang tua secara terus-menerus, untuk mencegah terjadinya masalah atau hambatan yang tidak bisa diduga.

Hambatan dalam perkembangan anak dapat terjadi dalam berbagai aspek. Menurut Wardaya (2015) aspek tumbuh kembang anak terdiri atas kemampuan kognitif, bahasa, motorik, sosio-emosional, agama dan moral. Menyoal proses tumbuh kembang anak, maka biasanya tak lepas dari gangguan atau hambatan dari proses tersebut. Salah satu gangguan atau hambatan yang kerap dialami oleh anak-anak adalah gangguan bicara dan bahasa. Hidayat (2005: 22-24) mengungkapkan bahwa kemampuan berbahasa ditandai dengan berbagai aspek, seperti kemampuan bersuara, tersenyum, berceloteh, berteriak, tertawa, menjerit, menoleh ke arah sumber bunyi, menggunakan vokalisasi semakin banyak, memiliki banyak perbendaharaan kata, mengombinasikan kata-kata, menunjukan lambaian anggota badan, mengenal dan responsif terhadap orang lain dan lain-lain. Kemampuan berbahasa semacam itulah yang akan berhubungan langsung dengan kemampuan berkomunikasi di masa yang akan datang.

Sebagai contoh kasus pada rubrik Konsultasi Perilaku Anak di Majalah Selaras Volume 54 edisi September 2015. Seorang ibu mengeluhkan akan keterlambatan perkembangan bicara anaknya yang berusia dua tahun. Selama ini orang tua anak tersebut lebih sering memberikan tayangan video anak agar orang tua tenang, sehingga orang tua anak tersebut bisa mengerjakan pekerjaan lain. Namun seiring waktu berjalan, orang tua baru menyadari bahwa kemampuan bicara anak mereka ternyata masih jauh dibanding teman sebayanya. Dalam kasus ini terkadang orang tua terlambat menyadari terjadinya sebuah keterlambatan perkembangan pada anak-anaknya dan bila hal ini sudah terlanjur terjadi maka sangat diperlukan pencarian solusi penyembuhannya secepat mungkin. Hal tersebut tentunya merupakan sebuah langkah yang sangat penting untuk diperhatikan oleh orang tua, yang mana para orang tua juga diharapkan untuk selalu memantau perkembangan buah hatinya.

Kemampuan berbicara merupakan kemampuan yang sangat penting bagi manusia. Karena kemampuan berbicara berkaitan dengan kemampuan berkomunikasi dan berkomunikasi merupakan sebuah hal yang tidak mungkin tidak dilakukan oleh manusia di muka bumi ini, terutama ketika bersinggungan dengan orang lain. Manusia juga bukan makhluk yang statis, melainkan ia senantiasa berproses dengan segala aspek kehidupannya termasuk dalam hubungan dan interaksinya dengan orang lain atau biasa disebut dengan komunikasi antarpribadi. Secara sederhana komunikasi antarpribadi dapat diartikan sebagai sebuah bentuk komunikasi seorang individu dengan individu lain dalam berbagai bentuk hubungan (Istiyanto, 2015). Bentuk komunikasi antarpribadi juga dapat berbentuk hubungan sebuah profesi dengan kliennya, sebagai contoh misalnya hubungan tenaga kesehatan dengan pasiennya. Dalam kaitannya dengan profesi tenaga kesehatan, maka terdapat istilah komunikasi terapeutik. Terapeutik merupakan kata sifat yang dihubungkan dengan seni dari penyembuhan (As Hornby dalam Nasir, 2009). 00

Penelitian mengenai komunikasi terapeutik sudah diteliti oleh banyak orang, namun yang berkaitan dengan penelitian ini seperti yang dilakukan oleh Ernia Ayu Karnia (2013) dengan judul Komunikasi Terapeutik Hypnodontia dalam Pengobatan Gigi dan Mulut berbicara mengenai proses dari komunikasi terapeutik menggunakan metode Hypnodontia pada pasien. Dari hasil penelitian, dijelaskan bahwa terdapat empat tahapan dalam proses komunikasi terapeutik yang dilakukan dokter gigi dengan menggunakan metode Hypnodontia 
yaitu: tahap prainduksi yang merupakan tahap dalam membangun relasi dengan pasien, yang kedua adalah tahap induksi yang membawa pasien menuju pikiran bawah sadar, kemudian deepening yang membawa pasien pada fase yang lebih dalam, dan yang terakhir adalah terminasi yang merupakan tahap terakhir dari metode ini yang ditandai dengan cara dokter mengembalikan keadaan dan pikiran bawah sadar pasien seperti semula. Jacklin Elisabet Monica Fisher (2011) juga melakukan penelitian dengan judul The Therapeutic Role of The Mental Health Nurse: Implications for The Practice Of Psychological Therapies. Dalam penelitian ini Jacklin menjelaskan bahwa adanya faktor intrinsik dan ekstrinsik dari diri seorang perawat sesungguhnya dapat berpengaruh terhadap kualitas pelayanan kesehatan serta dapat memberikan kontribusi pada peraturan MHN di jangka panjang.

Maka dari itu, sebuah proses komunikasi terapeutik sesungguhnya merupakan proses yang sangat penting dalam kaitannya dengan pemulihan pasien akan suatu keluhan tertentu, tak terkecuali untuk pasien anak-anak yang memiliki gangguan dalam aspek perkembangan. Dalam melakukan proses komunikasi terapeutik untuk anak, tentunya memiliki tingkat kesulitan yang lebih tinggi, apalagi bagi pasien yang mengalami hambatan dalam masalah berkomunikasi atau kemampuan reseptif dan ekspresif. Salah satu solusi penyembuhan dari timbulnya hambatan tersebut, adalah dengan melakukan sebuah terapi wicara.

Terapi wicara merupakan sebuah proses penyembuhan yang diperuntukan untuk menangani gangguan berbicara, bahasa dan motorik. Orang yang melakukan proses terapi wicara tersebut disebut sebagai terapis wicara. Peran seorang terapis sangatlah besar, selain harus mampu memahami kekurangan pasien terlebih dahulu, mereka juga harus memberikan sebuah terapi kepada pasien dengan cara-cara khusus demi meningkatkan proses kesembuhan pasien. Apalagi dalam menangani pasien anak-anak diperlukan kemampuan berkomunikasi dan kesabaran yang lebih, karena anak-anak lebih dinamis dan kadang terdapat keadaan yang tidak dapat diprediksi dan sulit diatur. Oleh karena itu, bagaimana proses komunikasi yang dilakukan oleh terapis dengan pasien anak dalam penyembuhan dalam pelayanan terapi wicara merupakan hal menarik untuk diketahui dan diteliti lebih lanjut.

Penelitian ini dilakukan di RSUD Prof. Dr. Margono Soekarjo Purwokerto. RSUD Prof. Dr. Margono Soekarjo Purwokerto merupakan Rumah Sakit kelas B pendidikan milik Provinsi Jawa Tengah yang menjadi pusat rujukan dari wilayah Jawa Tengah bagian barat dan selatan, termasuk rujukan pelayanan terapi wicara di wilayah eks karesidenan Banyumas. Berdasarkan data dari Instalasi Rehabilitasi Medik menunjukan bahwa tindakan yang dilakukan dalam pelayanan terapi wicara dalam bentuk terapi bicara dan bahasa menunjukan angka yang fluktuatif ditahun 2015 termasuk tindakan yang dilakukan bagi pasien anak down syndrome. Berdasarkan data dari RSUD Prof. Dr. Margono Soekarjo Purwokerto pada periode Januari-Desember 2015, diperoleh 7 pasien anak. Dalam penelitian ini jumlah yang digunakan hanya berjumlah tiga orang, mereka adalah daftar pasien yang rutin melakukan terapi wicara di RSUD Prof. Dr. Margono Soekarjo Purwokerto. Penelitian ini bertujuan untuk mengetahui lebih dalam tentang bagaimana dan seperti apa proses dari komunikasi terapeutik yang terjadi dalam hubungan terapis wicara dengan pasien anak penderita down syndrome di RSUD Prof. Dr. Margono Soekarjo Purwkerto.

\section{Metode}

Penelitian ini merupakan penelitian kualitatif yang bersifat eksploratif. Fokusnya adalah penggambaran secara menyeluruh tentang bentuk, fungsi dan makna ungkapan. Menurut Sukandarrumidi (2012:103), penelitian eksploratori adalah penelitian yang memiliki tujuan untuk mengenal serta mendapatkan pandangan baru akan suatu gejala yang sering kali mampu merumuskan masalah penelitian dengan lebih tepat. Penelitian ini dilakukan di 
Instalasi Rehabilitasi Medis bagian Terapi Wicara Rumah Sakit Umum Daerah Prof. Dr. Margono Soekarjo (RSMS) Purwokerto, yang berlokasi di Jl. Dr. Gumbreg Purwokerto, dengan teknik pengumpulan datanya menggunakan wawancara, obervasi dan dokumentasi. Pertama, wawancara dilakukan dalam bentuk semi-terstruktur yang sifatnya terbuka dan mendalam. Wawancara dilakukan kepada informan yang sudah dipilih melalui teknik purposive sampling. Menurut Sugiyono (2007:52), purposive sampling adalah teknik pengambilan sampel dengan berbagai pertimbangan-pertimbangan tertentu. Informan utama dalam penelitian ini adalah terapis wicara RSUD Prof. Dr. Margono Soekarjo Purwokerto yang berjumlah dua orang yaitu Zaki Mubarok dan Rina Triana serta orang tua pasien yang berjumlah tiga orang. Informan pendukungnya adalah dokter spesialis keterapian fisik dan rehabilitasi yaitu Massita Dwi Yuliani untuk memberikan keterangan mengenai kondisi secara medis anak penyandang down syndrome. Kedua, observasi dilakukan dengan melihat ekspresi dan sikap informan saat dilakukan wawancara mendalam. Hal tersebut dimaksudkan untuk mengetahui pemaknaan kejadian terkait pada bentuk perilaku yang ditunjukan. Menurut Herdiansyah (2010:136) behavioral checklist memiliki arti bahwa metode ini dapat memberikan keterangan tentang perilaku yang diobservasi dengan memberikan tanda checklist jika perilaku yang diobservasi muncul. Ketiga, dokumentasi dilakukan dengan pengumpulan buku-buku referensi. Satori dan Komariyah (2009: 149) menyebutkan bahwa studi dokumentasi dapat dilakukan dengan cara mengumpulkan dokumen dan data-data yang diperlukan dan kemudian ditelaah secara lebih intens dalam rangka menambah kepercayaan sekaligus menjadi bukti akan sebuah kejadian.

\section{Hasil dan Pembahasan}

\section{Jenis Metode Terapi Bahasa dan Bicara}

Metode modeling, self talk dan parallel talk digunakan dalam terapi bahasa. Dalam metode modeling, terapis menempatkan dirinya sebagai model yang kemudian pasien disuruh mencontohkan apa yang dilakukan terapis. Sementara itu, untuk metode self talk dan parallel talk merupakan metode yang juga bisa dipraktekan bagi orang tua. Self talk dilakukan dengan cara terapis akan berbicara apapun kepada anak, meskipun di sini jenis komunikasinya masih satu arah dan anak belum memberikan respon. Sementara itu, untuk parallel talk dilakukan dengan cara menanamkan konsep tertentu sehingga anak paham terhadap hal yang diajarkan, yang kemudian harapannya anak bisa menunjuk, menyamakan dan menamai sesuatu (Sahabat Sehat, 2013: 10).

Terapi bicara menggunakan menggunakan metode motokinestetik yang dapat diterapkan pada semua partisipan. Pada metode ini terapis melakukan teknik manipulasi langsung pada otot organ bicara atau organ perilaku komunikasi yang dianggap perlu. Metode yang kedua adalah metode stimulasi integral yang dilakukan berdasarkan rangsangan prinsip pengamatan terhadap suatu rangsangan secara terpadu melalui modalitas sensoris yang dimiliki seseorang yang dapat dipergunakan untuk memperbaiki komunikasi yang salah. Metode stimulasi integral ini bisa diterapkan kepada dua pasien, karena pada dasarnya mereka sudah lebih banyak mengucapkan kata-kata meskipun belum jelas. Metode terapi bicara yang digunakan terhadap pasien yang satunya lagi adalah metode modifikasi antara motokinestetik dan fonetic placement. Metode fonetic placement merupakan metode yang mengharuskan pasien untuk memperhatikan gerakan dan posisi organ bicara, sehingga pasien dapat mengendalikan pergerakan organ tersebut untuk menghasilkan perilaku komunikasi yang benar (Setyono, 2000: 115). Sementara ini program terapi yang dijalani oleh pasien adalah masih seputar pada terapi bahasa, belum kepada terapi bicara. Hal ini dikarenakan belum 
semua pasien mampu menunjukan respon bicara, dengan begitu program terapi yang dijalankan belum bisa masuk kepada program terapi bicara.

Dengan digunakannya metode-metode tersebut, maka hal ini sesuai dengan salah satu prinsip dari komunikasi terapeutik, bahwa komunikasi terapeutik merupakan proses komunikasi yang berorientasi pada proses percepatan kesembuhan (Nasir dkk, 2009: 167169), meskipun sebenarnya kondisi semacam down syndrome tidak dapat disembuhkan, namun minimal dapat dikembangkan melalui terapi yang dijalani pasien.

\section{Proses Komunikasi Terapeutik}

Jenis komunikasi terapeutik yang dibahas dalam penelitian ini adalah komunikasi terapeutik yang bertujuan untuk mencapai tingkat kesehatan klien semaksimal mungkin yang mana hal ini dicapai dengan cara memberikan perawatan secara komprehensif melalui pertukaran informasi yang mampu meningkatkan koordinasi dan kesinambungan pelayananan kesehatan terhadap klien (Priyanto, 2009:9). Tindakan terapi yang biasa dilakukannya pada pasien down syndrome merupakan jenis tindakan yang sifatnya meningkatkan atau mengembangkan kemampuan. Secara umum, memang biasanya anak-anak down syndrome memiliki kekurangan atau keterbelakangan dalam berbagai aspek, misalnya kemampuan motorik kasar, motorik halus serta bahasa, jadi sifat tindakannya lebih mengarah pada tindakan promotif yang sifatnya meningkatkan dan mengembangkan kemampuan perilaku komunikasi. Awal mula rehabilitasi medik diperuntukan bagi orang-orang dalam kondisi cacat, namun kini lebih luas termasuk gangguan tumbuh kembang juga. secara khusus gangguan tumbuh kembang pada down syndrome untuk terapi wicara lebih kepada membantu kemampuan bahasa dan bicaranya namun sifatnya bukanlah menyembuhkan karena kondisi down syndrome memang tidak dapat sembuh.

Tujuan dilakukannya terapi wicara di sini tidak hanya untuk melatih kemampuan berbicara, namun juga untuk memberikan pemahaman akan pentingnya berhubungan sosial dengan orang lain. Maka, komunikasi terapeutik yang dilakukan terapis wicara dengan pasien anak penyandang down syndrome di RSUD Prof. Dr. Margono Soekarjo Purwokerto (RSMS) memiliki beberapa proses dan tahapan yang berkesinambungan. Tahap-tahap tersebut di antaranya adalah tahap pra interaksi, perkenalan, orientasi, kerja, dan terminasi (Nasir dkk, 2009:170). Dalam prosesnya banyak dilakukan komunikasi verbal yang juga ditegaskan atau diiringi dengan komunikasi non-verbal, karena komunikasi non-verbal memang ditujukan untuk melengkapi dan menegaskan makna dari komunikasi verbal yang dilakukan oleh seseorang.

\section{Tahap Pra Interaksi}

Merupakan tahap awal yang mana terapis mulai menggali kemampuan yang dimiliki sebelum melakukan kontak dengan pasien. Terapis harus memahami dulu kondisi pasien yang akan ditangani termasuk kebiasaan sehari-harinya yang mungkin masih terbawa ke Rumah Sakit. Dalam proses terapi wicara, biasanya observasi awal dengan cara melihat dari kondisi awal si anak, apakah anak tersebut mampu langsung diajak interaksi atau tidak. Menurut penuturan beliau, pada tahap awal jika dilihat anaknya kooperatif langsung dapat dilakukan interaksi, namun jika tidak maka akan dibiarkan terlebih dahulu mengikuti kemauan dan prilaku sang anak. Jika si anak menangis, langkah yang dilakukan juga akan didiamkan terlebih dahulu agar anak dapat meluapkan emosinya. 


\section{Tahap Perkenalan}

Merupakan tahap yang mana terapis mulai memperkenalkan diri pada klien ataupun keluarganya. Dalam tahap ini diharapkan adanya keterbukaan dari klien agar proses komunikasi terapeutik yang akan dilakukan dapat berjalan dengan lancar. Tahapan ini masih berkaitan dengan tahap pra interaksi. Terapis harus berusaha membangun interaksi dengan pasien. Pada tahapan ini biasanya terapi akan berusaha mengajak berkenalan dengan anak dengan cara mengajak sang anak untuk berjabat tangan. Terkadang ada yang menurut ada juga yang tidak menurut atau masih malu-malu, kemudian dilanjutkan komunikasi dengan orang tua pasien yang dalam hal ini telah masuk pada tahap orientasi. Selanjutnya, terapis akan tetap menyesuaikan dengan prilaku anak terlebih dahulu atau dengan kata lain terapis tidak langsung melakukan proses terapi. Jadi pada tahap ini hampir sama mekanismenya dengan tahap pra interaksi. Terapis harus mampu menyesuaikan diri dan lingkungan dengan kondisi anak. Ada tipe anak yang interaktif, yang tentunya akan memudahkan untuk dimulainya terapi, namun hal itu jarang terjadi karena anak-anak lebih sering menangis ataupun diam.

\section{Tahap Orientasi}

Pasien bertemu dengan dokter dahulu untuk diketahui diagnosanya, barulah dilakukan tindakan terapi berdasarkan petunjuk dokter. Dalam tahap ini terapis mencari tahu masalah dan keluhan yang dialami pasien yang akan menentukan rencana tindakan yang harus dilakukan. Biasanya terapis akan melihat kondisi pasien secara fisik yang kemudian dilanjutkan dengan bertanya langsung pada orang tua pasien tentang kondisi sang anak, sekaligus menyusun rencana tindakan. Hal ini dikarenakan orang tua yang mengerti tentang kondisi anak.

\section{Tahap Kerja}

Tahapan ini merupakan pengimplementasian dari rencana kegiatan yang telah dibuat. Pada tahap ini langsung dimulai proses terapi serta proses komunikasi terapeutik. Proses komunikasi terapeutik yang dilakukan pada dasarnya sama dengan proses komunikasi pada umumnya, yaitu dengan adanya unsur komunikator, komunikan, pesan, media serta feedback atau umpan balik. Hanya saja konteks komunikasi yang dilakukan dalam hal ini adalah dimaksudkan untuk meningkatkan kemampuan dari pasien yang pada akhirnya lebih mengarah pada proses perbaikan menuju keadaan yang lebih baik.

\section{Tahap Terminasi}

Tahap terminasi merupakan tahap terakhir dalam proses terapi. Dapat dikatakan bahwa dalam tahap ini dapat dilakukan proses evaluasi untuk merumuskan tindakan yang akan dilakukan dalam sesi terapi selanjutnya. Pada program terapi wicara pada anak biasanya terapis akan melakukan penutup dengan cara mengucapkan ucapan terima kasih dan salam. Terapis tetap membatasi waktu terapi agar anak juga terbiasa disiplin. Seusai terapi, terapis juga membiasakan untuk mengajarkan tata krama jika melakukan perpisahan dengan cara cium tangan. Dan jika masih ada yang berusaha bermain, maka sebisa mungkin permainannya harus disingkirkan agar anak mengerti bahwa sesinya telah usai.

Berdasarkan hal tersebut proses tersebut, salah satu prinsip dari komunikasi terapeutik, bahwa komunikasi terapeutik merupakan komunikasi yang terstruktur dan direncanakan (Nasir dkk, 2009: 167-169). Tindakan yang terstruktur dan direncanakan tersebut jelas tercermin dari aspek perencanaan yang diterapkan terapis pada awal terapi hingga pada tahap 
diakhirinya proses terapi. Penyusunan tindakan tersebut juga bukanlah tanpa dasar, terapis mampu melihat kondisi anak sehingga mereka bisa menentukan tindakan yang dilakukan. Penyusunan komunikasi yang terstruktur dan direncanakan juga menimbulkan hasil timbal balik yang sesuai dengan harapan.

\section{Komunikasi Non-Verbal untuk anak Down Syndrome Selama Terapi}

Bentuk-bentuk komunikasi nonverbal dalam konteks ini lebih mengarah pada ciri khas dari masing-masing terapis. Salah satu prinsip dari komunkasi terapeutik adalah bahwa komunikasi terapeutik merupakan komunikasi yang memperhatikan konteks topik, ruang dan waktu (Nasir dkk, 2009: 167-169). Dalam menangani pasien setiap terapis memiliki cara sendiri yang mungkin berbeda dengan terapis lain dan semua cara tersebut dapat diklasifikasikan ke dalam bentuk komunikasi nonverbal yang sesungguhnya terdapat maknamakna tertentu.

\section{Sentuhan}

Dalam proses terapi, ada satu jenis komunikasi non-verbal yang tidak dapat dihindari dan tidak mungkin tidak dilakukan, yaitu sentuhan (haptika). Selama terapi, terapis kerap kali melakukan sentuhan yang terbilang beragam bentuknya. (1) Menggelitik. Menggelitik merupakan cara yang dilakukan oleh terapis dalam kesehariannya menangani pasien anak down syndrome. Misalnya terhadap pasien yang masuk dalam kategori anak yang aktif dan terkadang menjadi hiperaktif. Ia seringkali bergerak ke sana ke mari maka dari itu, terapis seringkali melakukan bentuk komunikasi non-verbal dengan cara menggelitik. Selain itu, menggelitik juga dilakukan ketika anak tidak memberikan respon, ataupun ketika anak mulai ngambek dan tidak mau menuruti perintah dari terapis. Biasanya anak akan memberikan respon jika dilakukan tindakan menggelitik ini berupa reaksi tertawa ataupun menangis. Selain itu, tujuan dari menggeletik ini adalah agar anak kembali fokus terhadap materi bukan terhadap hal-hal lain yang mungkin kerap mengalihkan fokus perhatiannya dalam proses terapi. (2) Memegang atau Menggenggam tangan. Terapis kerap kali memegang atau menggenggam tangan pasien, hal ini dimaksudkan agar pasien bisa dikendalikan. Berdasarkan hasil observasi peneliti, dalam situasi tertentu pasien berada dalam kondisi yang agak sulit diatur dan mulai menunjukan sikap semaunya sendiri, misalnya ia berusaha melempar mainan yang ada di depannya. Bila dalam kondisi seperti itu terapis lansung memegang tangannya dan terkadang juga disertai sedikit tekanan pada tangan pasien. Hal ini dilakukan selain untuk mengendalikan perilaku pasien, juga bertujuan untuk memberikan pemahaman agar si anak merasakan perbedaan penekanan pada tangannya yang artinya memberi pemahaman bahwa bila kondisi tangannya agak ditekan seperti itu tandanya ada sesuatu yang dilarang. Terapis juga kerap memegang tangan pasien ketika beliau mengajarkan kata-kata untuk ditiru ucapannya oleh pasien. Contohnya saat terapis menyuruh pasien untuk mengucapkan "oke" beliau memegang tangan pasien dan mengarahkan tangannya berputar di depan mulut terapis yang berucap "oke". Hal ini dimaksudkan agar pasien tertarik untuk meniru dan ini juga merupakan gaya khas dari terapis. (3) Berjabat Tangan. Berjabat tangan adalah hal yang pasti dilakukan oleh terapis ketika proses terapi baru dimulai. Tujuannya untuk membiasakan anak agar mengenal orang yang ada di depannya. Kemudian, berjabat tangan juga dilakukan ketika proses terapi telah selesai. Berjabat tangan juga merupakan salah satu hal yang wajib dilakukan untuk mengajarkan tata krama dan kebiasaan baik kepada anak, sehingga anak akan terus mengingat apa yang sudah menjadi kebiasaan dalam proses terapi dan harapannya bisa diterapkan dalam kehidupan sehari-harinya. (4) Sentuhan Langsung. Bentuk dari gerakan menyentuh lainnya biasanya dengan dilakukannya sentuhan secara langsung yang bermaksud 
untuk menunjukan hal-hal yang lebih spesifik, seperti untuk mengajarkan pasien dalam mengenal anggota tubuh, menenangkan kondisi serta memberikan rangsangan untuk melakukan hal yang diperintahkan. Bentuk komunikasi non-verbal melaluui sentuhan memang lebih diarahkan untuk memberikan stimulus dalam materi. Misalnya materi untuk menunjuk anggota tubuh seperti mata ataupun hidung. Atau bisa juga terapis menyentuh sang anak dengan tujuan menenangkan ketika anak memberikan reaksi berlebihan.

\section{Gerakan Anggota Tubuh}

Dalam proses terapi, gerakan tos, bertepuk tangan dan mengatakan "yes" menjadi sebuah gerakan yang sering dilakukan berulang-ulang, terutama ketika pasien berhasil melakukan suatu perintah yang diberikan. Hal ini dilakukan untuk menciptakan sebuah interaksi yang bersahabat serta suasana yang menyenangkan, karena anak-anak adalah tipe yang sangat senang bermain, maka diperlukan penghargaan ketika mereka mampu atau berhasil melakukan suatu perintah, dengan begitu mereka tentunya akan merasa dihargai dan tercipta makna di dalam pikiran mereka bahwa apa yang mereka lakukan adalah benar karena bisa mendapatkan pujian dari orang lain.

\section{Orientasi Ruang dan Jarak Pribadi}

Dalam proses terapi terdapat orientasi ruang dan jarak pribadi yang diciptakan terapis. Terapi yang dilakukan biasanya selalu menggunakan meja dan kursi di antara terapis dan pasien, hal ini dimaksudkan agar pasien mampu memahami bahwa mereka datang ke tempat terapi adalah untuk belajar, sehingga mereka harus duduk di kursi dan sudah disediakan meja untuk melakukan aktivitasnya.

Kursi yang disusun pun harus menempel tembok, jangan sampai jarak antara kursi dengan tembok terlalu jauh. Hal ini dimaksudkan agar pasien bisa tenang ketika belajar dan tidak mudah keluar dari kursi. Terapi mungkin saja dilakukan tanpa menggunakan kursi, namun hal itu diperuntukan bagi anak-anak yang memiliki postur tubuh yang kecil yang dikhawatirkan nantinya justru akan menyulitkan proses terapi ketika mereka dipaksa tetap dalam kursi. Bila dalam kondisi seperti ini, terapis akan memangku sang anak dan mereka akan duduk menghadap ke cermin. Di sini cermin berperan sebagai media untuk mndapatkan feedback atau umpan balik dari pasien selama proses terapi. Selain itu, ruangan dari terapi juga didesain sedemikian rupa dengan tujuan membuat anak senyaman mungkin dalam proses terapi. Hal ini terlihat dari ruangan terapi wicara yang dicat warna-warni, dilengkapi berbagai aksesoris serta peralatan atau media yang memadai.

\section{Vokalika/ Parabahasa}

Parabahasa atau vokalika merujuk pada aspek-aspek suara selain ucapan yang dapat dipahami, misalnya kecepatan bicara, nada, intensitas (volume) suara, intonasi, kualitas vokal, warna suara, dialek, suara serak, suara sengau, suara putus-putus, suara yang gemetar, suitan, siulan, tawa, erangan, tangis, gerutuan, gumaman, desahan dan lain-lain (Mulyana, 2011: 387). Dalam hal vokalika, aspek yang sering ditunjukan oleh terapis adalah (1) Nada dan Intonasi. Untuk masalah nada, tergantung dari gaya masing-masing terapis. Misalnya menggunakan nada yang pelan, tinggi dan tegas bila dalam kondisi anak sedang sulit diatur kemudian didukung dengan menyentuh bagian tubuh anak dan diarahkan untuk melakukan sesuatu. Dalam proses terapi jarang sekali dilakukan tindakan secara tegas seperti membentak, sehingga instruksi lebih banyak dilakukan melalui proses komunikasi non-verbal. Penggunaan nada yang sedikit meninggi biasanya dilakukan kala pasien mulai malas dan tidak mau mengikuti instuksi terapis didukung dengan raut ekspresi yang menunjukan seseorang marah, 
namun tidak sampai mengeluarkan nada keras. (2) Kualitas vokal (kejelasan). Untuk aspek kualitas vokal, merujuk pada kejelasan dari suara yang disampaikan terapis. Suara yang dikeluarkan oleh terapis selama proses terapis terdengar sangat jelas dan cukup keras karena terkadang bisa terdengar hingga ke luar ruangan. Hal ini tentunya dimaksudkan agar anak dapat mendengar yang harapannya juga sekaligus memahami tentang kalimat yang diucapkan oleh terapis. Hal ini juga berkaitan dengan metode dari terapi bahasa yang digunakan dalam proses terapi ini, yaitu metode modelling. Kualitaas vokal juga sangat diperhatikan karena ini merupakan bagian dari pembelajaran pasien. Sebagai contoh, untuk mengajarkan pasien agar dapat berbicara dengan jelas, maka terapis juga mengajarinya dengan menunjukan kualitas vokal sejelas mungkin agar mudah dipahami dan ditiru oleh pasien.

\section{Kontak Mata}

Kontak mata merupakan hal yang sangat berpengaruh dalam proses komunikasi terutama ketika seseorang berkomunikasi dengan orang lain secara langsung atau tatap muka. Liliweri (2015: 470) mengatakan bahwa kontak mata merupakan hal yang penting, karena mampu menjaga aliran percakapan sekaligus mengukur respon dari orang lain. Kontak mata merupakan hal yang paling utama dilakukan dalam interaksi, melalui kontak mata bahkan terapis dapat merasa dan menebak apa yang sedang dirasakan oleh pasien. Sehingga hal ini menjadi sebuah komponen interaksi yang paling penting dalam proses terapi. Dalam proses terapi, terlihat jelas bahwa terapis selalu melakukan kontak mata dengan pasien sepanjang durasi. Hal ini juga dimaksudkan agar pasien mampu fokus tehadap materi yang diberikan.

\section{Konsep Waktu}

Kronemika merupakan studi dan interpretasi waktu sebagai sebuah pesan, yang berkaitan dengan bagaimana kita mempersepsi dan memperlakukan waktu secara simbolik dapat menunjukan sebagian dari jati diri kita, misalnya mengenai siapa diri kita dan bagaimana kesadaran kita akan lingkungan. Penganut waktu monokronik cenderung mempersepsi waktu dengan berjalan lurus dari masa silam ke masa depan sehingga menekankan penjadwalan dan kesegaran waktu (Mulyana, 2011: 416-417). Terapis memperhatikan ketepatan waktu dan durasi selama berlangsungnya terapi. Hal tersebut terlihat dari intensitas terapis melihat jam tangannya dari awal terapi dimulai dan selama proses terapi berlangsung. Durasi memang menjadi hal yang sangat berpengaruh dalam proses terapi dan pembatasan waktu selama 30 menit pada setiap proses terapi menjadi hal yang mutlak.

\section{Warna}

Warna menjadi hal juga mampu mempengaruhi kondisi ruangan terapi. Ruangan terapi wicara memiliki warna dinding yang cerah yaitu perpaduan antara warna hijau, kuning, biru dan merah. Hal tersebut memang sengaja dilakukan. Pewarnaan yang bervariasi dengan tujuan untuk memberikan rasa nyaman, ceria dan senang bagi pasien, terutama pasien anakanak. Perlu juga dihindari pewarnaan yang terlalu gelap yang nantinya bisa membuat keadaan di lingkungan terapi menjadi kurang nyaman karena bagaimanapun warna dapat mempengaruhi keadaan psikologis seseorang.

\section{Hambatan Selama Proses Terapi}

Dalam melakukan prosesi terapi wicara, terdapat hambatan-hambatan dialami oleh terapis yang tentunya bisa mempengaruhi proses dari jalannya terapi tersebut. Hambatan tersebut berasal dari dalam maupun dari luar. 


\section{Hambatan Internal}

Hambatan internal merupakan hambatan yang berasal dari dalam diri terapis. Terdapat hambatan yang sifatnya berkaitan dengan diri terapis yang juga berhubungan institusi itu sendiri, di antaranya adalah kurangnya sarana dan prasarana yang diperlukan dalam proses terapi dan skill atau kemampuan dari terapis yang masih perlu ditingkatkan demi memberikan pelayanan yang lebih baik lagi.

\section{Hambatan Eksternal}

Hambatan eksternal terdiri dari (1) Durasi Terapi. Durasi terapi di Rumah Sakit sangatlah terbatas hanya berkisar 30 menit untuk setiap terapinya, hal ini menjadi sebuah hambatan bagi terapis yang mengakibatkan terapis harus benar-benar memperhatikan waktu terapi dengan penyampaian materi yang semaksimal mungkin. (2) Orang tua pasien yang kurang kooperatif. Terkadang ada tipe orang tua yang hanya membawa anaknya untuk terapi di Rumah Sakit saja tanpa pernah mengulangi materi terapi yang dianjurkan di rumah. Hal ini bisa memperlambat proses terapi yang dilakukan sehingga kemampuan anak untuk berkembang juga bisa semakin lama. Hal ini perlu menjadi perhatian karena waktu pasien akan lebih banyak dilalui ketika mereka bersama keluarganya. Jika keluarga pasien terutama orang tua mampu memantau perkembangan anak mereka dengan maksimal, maka semakin tinggi presentase peningkatan kemampuan pasien

\section{Analisis Teori Transaksional}

Terapi dilakukan hanya kepada individu yang memiliki masalah atau ada hal-hal yang tidak sebagaimana mestinya dalam hidupnya. Hal tersebut tercermin dari adanya penyelenggaraaan terapi bagi anak-anak dengan kondisi down syndrome yang memiliki masalah perkembangan dalam hal bahasa dan bicara. Berne dalam Santoso dan Setiansah (2010) mengatakan beberapa asumsi, yaitu: (1) Manusia pada dasarnya dalam keadaan oke dan masing-masing manusia selalu memiliki nilai, berguna, serta memiliki kemampuan tertentu sehingga patut diperlakukan dengan layak. (2) Semua orang memiliki kapasitas untuk berpikir dan (3) Manusia dapat memutuskan sendiri jalan hidup mereka meskipun keputusan tersebut dapat diubah.

Berdasarkan asumsi tersebut maka dapat dikatakan bahwa masing-masing anak penyandang down syndrome meskipun ia memiliki kekurangan, namun pada dasarnya mereka tetap memiliki nilai, berguna dan kemampuan tertentu yang mungkin belum tentu dimiliki oleh anak-anak dengan kondisi normal. Anak-anak penyandang down syndrome patut diperlakukan dengan layak. Peran terapi di sini adalah mencoba untuk meningkatkan taraf hidup mereka ke arah yang lebih baik, hingga suatu saat nanti mereka dapat memutuskan sendiri jalan hidup yang akan mereka tempuh.

Terapis menggunakan dua ego state selama proses terapi yaitu ego state dewasa (Adult). Digolongkan ke dalam ego sate dewasa karena terapis mampu menilai fakta yang diperoleh melalui panca inderanya dan menghasilkan solusi yang masuk akal. Hal ini tercermin dari bagaimana terapis memulai observasi pasien pada awal terapi hingga memutuskan jenis tindakan terapi yang harus dilakukan sekaligus dengan metode yang dipilihnya. Terapis juga melakukan penalaran, tidak dikuasai oleh emosi dan berkomunikasi secara dua arah, baik itu dengan pasien maupun dengan orang tua pasien. Kata-kata yang diucapkan juga jelas dan hati-hati dengan ekspresi wajah yang tenang.

Dalam sudut pandang pasien anak, mereka terlihat jelas menggunakan ego state anakanak dalam kategori Adapted Child. Ada yang masuk pada kategori anak penurut yang mau melakukan apa yang diperintahkan dan anak pemberontak yang menolak apa yang 
diperintahkan. Setiap anak akan selalu menjadi golongan anak yang penurut dan pemberontak sekaligus. Hal tersebut terlihat saat ada pasien yang tidak mau menuruti perintah terapis, namun ada juga yang menurut. Memang hal tersebut hanya terjadi pada waktu-waktu tertentu saja dalam proses terapi dan lebih terlihat pada perilaku non-verbalnya, tidak secara verbal.

Dalam konteks transaksi yang terjadi terjadi di antara diri pasien dan terapis ketika mereka berkomunikasi secara non-verbal merupakan jenis transaksi komplementer dan bentuk komunikasi verbal yang terjadi masuk dalam kategori transaksi silang. Transaksi komplementer (complementary transaction) artinya terjadi timbal balik yang setimpal dan hubungan komunikasi dapat tetap dilanjutkan karena makna yang diharapkan dapat diterima oleh lawan bicara. Sementara itu, untuk bentuk komunikasi verbal dapat dikatakan dalam transaksi silang (crossed transaction) yang artinya pesan yang dikirimkan terapis tidak selalu mendapat respon yang sesuai dengan yang diharapkan (Solomon, 2003: 18).

Pada konteks hubungan antar pasien dan terapis sifatnya juga tergolong cukup intens, sehingga mereka memiliki kedekatan personal meski harus melalui beberapa kali pertemuan. Seorang anak yang menderita kondisi down syndrome dalam usia ini sudah bisa memahami dan mengenal orang yang kerap bertemu dengannya. Peneliti menilai dalam proses terapi terjadi sebuah proses komunikasi dengan feedback meski tidak selalu sesuai dengan yang diharapkan.

\section{Simpulan}

Berdasarkan hasil uraiandi atas, maka dapat diambil simpulan bahwa metode terapi bahasa yang dipakai terapis dalam menangani pasien anak down syndrome di RSUD Prof. Dr. Margono Soekarjo Purwokerto terhadap tiga pasien adalah metode modelling dan self talk dan parallel talk. Dalam metode modelling, terapis menempatkan dirinya sebagai model yang kemudian pasien disuruh mencontohkan apa yang dilakukan terapis. Sementara itu, untuk metode self talk dan parallel talk dilakukan dengan cara berbicara pada anak dengan keras dengan tujuan agar anak mendengar setiap ucapan atau kata yang diucapkan oleh terapis ataupun orang tua. Selanjutnya, anak diajak berbicara dengan terapis atau orang tuanya. Proses komunikasi terapeutik dalam terapi dilakukan dengan beberapa tahapan, (1) Tahap pra interaksi, yakni terapis berusaha untuk membangun interaksi dengan anak. (2) Tahap perkenalan, yaitu terapis harus berkenalan dulu dengan sang anak serta orangtuanya termasuk mulai merencanakan proses terapi yang akan dilaksanakan. (3) Tahap orientasi, yaitu terapis akan mencari tahu masalah dan keluhan yang dialami pasien yang akan menentukan rencana tindakan yang harus dilakukan. (4) Tahapan kerja merupakan tahap pengimplementasian dari rencana kegiatan yang telah dibuat. Pada tahap ini akan langsung dimulai proses terapi serta proses komunikasi terapeutik. (5) Tahap terminasi, yang merupakan tahap terakhir dalam proses terapi. Dalam tahap ini dapat dilakukan proses evaluasi untuk merumuskan tindakan yang akan dilakukan dalam sesi terapi selanjutnya.

Dalam proses komunikasi terapeutik, terapis juga kerap menggunakan bentuk komunikasi verbal dan non-verbal. Bentuk komunikasi verbal banyak dilakukan ketika terapis memberikan perintah-perintah tertentu kepada pasien, sementara komunikasi non-verbal dapat berupa sentuhan, gerakan tos, bertepuk tangan, dan mengatakan "yes", Orientasi ruang dan jarak pribadi, dan vokalika/ parabahasa.

Dalam proses terapi, juga terdapat hambatan-hambatan yang kerap dialami terapis, di antaranya adalah sarana dan prasarana yang perlu dilengkapi dalam proses terapi, skill atau kemampuan terapis yang masih perlu ditingkatkan, durasi terapi yang relatif singkat, serta orang tua pasien yang kurang kooperatif. 
Down Syndrome Melalui Pelayanan Terapi Wicara...

\section{Referensi}

Anonim. (2015). Perkembangan Bicara Anak Jauh dari Teman Sebayanya. Semarang: Selaras.

Ernia, A. K. (2013). Komunikasi Terapeutik Hypnodontia dalam Pengobatan Gigi dan Mulut. Universitas Padjajaran, Bandung, Indonesia.

Fisher, J. E. M. (2011). The therapeutic role of the mental health nurse: implications for the practice of psychological therapies. Lismore, NSW: Southern Cross University, Australia.

Herdiansyah, H. (2010). Metodologi Penelitian Kualitatif. Jakarta: Salemba Humanika

Hidayat, A. A. (2005). Pengantar Ilmu Keperawatan Anak 1. Jakarta: Salemba

Istiyanto, S. B. (2015). Komunikasi Antarpribadi. Purwokerto: Literasi Bangsa

Liliweri, A. (2015). Komunikasi Antarpersonal. Jakarta: Kencana Medika.

Mulyana, D. (2011). Ilmu Komunikasi Suatu Pengantar. Bandung: PT Remaja Rosdakarya

Nasir, A. dkk. (2009). Komunikasi dalam Keperawatan. Jakarta: Salemba Medika

Priyanto, A. 2009. Komunikasi dan Konseling, Aplikasi dalam Sarana Pelayanan Kesehatan untuk Perawat dan Bidan. Jakarta: Salemba Medika

Sahabat, Sehat. Edisi Juli-September 2013. Majalah Rumah Sakit Pantai Indah Kapuk

Santoso, E., Setiansah, M. (2010). Teori Komunikasi. Yogyakarta: Graha Ilmu

Satori, D., Komariah, A. (2009). Metodologi Penelitian Kualitatif. Bandung: Alfabeta

Selaras Media. (2015, September, Volume 54). Rubrik Konsultasi Prilaku Anak. Semarang

Setyono, B. (2000). Terapi Wicara Untuk Praktisi Pendidikan \& Kesehatan. Jakarta: Penerbit Buku Kedokteran EGC

Solomon, C. (2003). Transactional Analysis Theory: The Basic. Volume 33, No. 1, Januari 2003. (Online). Tersedia dari: http://www.carolsolomonphd.com/ web_pdfs/Transact. pdf, diakses pada 24 Januari 2016. California.

Sugiyono. (2007). Memahami Penelitian Kualitatif. Bandung: Alfabeta

Sukandarrumidi. (2012). Metodologi Penelitian; Petunjuk Praktis untuk Peneliti Pemula. Yogyakarta.

Wardaya, C, U. (2015). Identifikasi Potensi Kemampuan Anak Usia Dini. Artikel PPPPTK DAN PLB. (Online). Tersedia dari: http://www.tkplb.org/index.php/11-warta/70identifikasi-potensi-kemampuan-anak-usia-dini diakses pada 29 September 2015 